\title{
Increase in outdoor carbon dioxide and its effects on the environment and human health in Kuje FCT Nigeria
}

\author{
L. E. Okobia*, , S. M. Hassan*, and Adakayi Peter \\ *Department of Geography and Environmental Management, University of Abuja, FCT, Nigeria. \\ ${ }^{\dagger}$ F. P. Lympson, Suite 10, Dansville Plaza, Gudu District Abuja, Nigeria.
}

\begin{abstract}
Globally there are concerns about outdoor air pollution and its effects on the environment and human health. Researchers are concerned with the negative effects of and best mitigation strategies for air pollution. Climate change and human health are a common phenomenon associated with air pollution, as carbon dioxide $\left(\mathrm{CO}_{2}\right)$ is absorbed and emitted naturally as part of the carbon cycle. This study was aimed at assessing the emission level of $\mathrm{CO}_{2}$ in Kuje Area Council in the Federal Capital Territory, Nigeria and its effect on the environment and human health. Fifty specific residential and commercial locations were considered, and over 1200 observations of $\mathrm{CO}_{2}$ field data were collected and analysed during two seasons-dry and wet. The land-use settlement pattern was taken into consideration. The data were collected weekly at different time bands (2-, 4-, 6-, and 8-hour time intervals) using the AMPROBE $\mathrm{CO}_{2}-100, \mathrm{CO}_{2}$ meter gas detection instrument with self-calibration capability of \pm 30 parts per million ( $\mathrm{ppm}), \pm 5 \%$ reading $(0-5000)$ accuracy. A Garmin CX60 global positioning system was used to obtain the point locations Universal Transvers Mercator coordinates. The results showed higher mean $\mathrm{CO}_{2}$ emission values of $>541 \mathrm{ppm}$ and $<713 \mathrm{ppm}$ during the dry and wet seasons, respectively. It was also observed that these values were contrary to and exceeded the American Society of Heating, Refrigerating and AirConditioning Engineers and Occupational Safety and Health Administration normal outdoor level standards of 350-450 $\mathrm{ppm}$. These higher $\mathrm{CO}_{2}$ values were found in the residential and commercial districts, and if not monitored and controlled they will have adverse effects on human health and climate change effects. Quick interventions would be to plant trees to sequestrate the $\mathrm{CO}_{2}$ and to regulate the transportation system within the area due to continuous carbon emission.
\end{abstract}

Key words: carbon dioxide, climate change, human health, emission levels.

\section{Introduction}

There have been continuous discussions on climate change and the role of air pollution globally. This has stimulated many global studies, articles, and publications on climate change and its effect on economy, human health, and the environment. The discussions are skewed in the direction of greenhouse gas (GHG) emissions, most importantly that the GHGs directly emitted by humans, such as methane $\left(\mathrm{CH}_{4}\right)$, nitrous oxide $\left(\mathrm{N}_{2} \mathrm{O}\right)$, carbon dioxide $\left(\mathrm{CO}_{2}\right)$, and several others. GHG emissions are often measured in a $\mathrm{CO}_{2}$ equivalent according to United States Environmental Protection Agency (USEPA, 2016). Transportation is the second largest source of $\mathrm{CO}_{2}$ emissions, accounting for about $31 \%$ of total U.S. CO emissions and $26 \%$ of total US GHG emissions in 2011 ('Thind, 2013). Carbon dioxide also enters the atmosphere through burning of fossil fuels, municipal solid waste, trees and wood products, and because of certain chemical reactions. It is also removed from the atmosphere or "sequestered" when it is

Corresponding author: $x x x x$ absorbed by plants as part of the biological carbon cycle (USEPA, 2016). The increase in GHG emissions is generating more data-informed research on several causes of the change in climatic conditions and the resultant effects on the environment. The American Society of Heating, Refrigerating and AirConditioning Engineers (ASHRAE) and Occupational Safety and Health Administration (OSHA) normal standards for the outdoor levels of $\mathrm{CO}_{2}$ is 350-450 parts per million (ppm), which is used for the purpose of this study. In August 2016, the Mauna Loa Observatory in Hawaii noted that the mean monthly average measurement of $\mathrm{CO}_{2}$ increased from 398.93 ppm in 2015 to 402.25 ppm a year later (United States Earth System Research Laboratory (ESRL) and National Oceanic and Atmospheric Administration (NOAA), 2016). If this increases more in the atmosphere and displaces oxygen $\left(\mathrm{O}_{2}\right)$ significantly, it will contribute to toxicity (Rice, 2004) and will clearly contribute to poor indoor air quality (Miller et al., 2010), because the changes in the $\mathrm{CO}_{2}$ level impacts fungal growth medium to induce allergies (Lang-Yona et al., 2013). For every 1 degree rise in temperature caused by $\mathrm{CO}_{2}$, cancers may increase by $20 \%-30 \%$ (Kalaugher, 2008). When the body 
is exposed to too much $\mathrm{CO}_{2}$, internal respiration is affected and a person may experience symptoms such as asphyxiation, frostbite, kidney damage, or coma (Thind, 2013).

Deforestation is an environmental challenge that contributes to increased weather conditions and climate change effects. Between 2008 and 2016, trees removed from the Kuje Area Council Federal Capital Territory (FCT) resulted in an arithmetic difference of $0.0283 \mathrm{~km}^{2}(40.67 \%)$. This translates to an equivalent of over 9.6 tons of $\mathrm{CO}_{2}$ that was not sequestered due to deforestation. An increase in tree cover provides more resistance to extreme weather and improves photosynthesis; therefore, a decrease in trees to sequestrate $\mathrm{CO}_{2}$ presents a challenge (Badaru et al., 2016). High concentrations of $\mathrm{CO}_{2}$ in residential settlements or commercial workplaces can cause adverse health effects such as, but not limited to, dizziness, suffocation, disorientation, and under certain circumstances, death. (Farrar et al., 1999; IVHHN, 2005; Nelson, 2000; NIOSH, 1976, 1996). Owing to the observed environmental $\mathrm{CO}_{2}$ issues, behavioural toxicity levels are inevitable; however, re-evaluation of existing standards for the maximum allowable concentrations is considered (Vercruyssen et al., 2007 ). In the FCT, increased anthropogenic activities contribute immensely to the outdoor pollution (Abdullahi et al., 2012; Okobia, 2012), it is of utmost necessity that the outdoor $\mathrm{CO}_{2}$ level is quickly assessed in the FCT.
The aim of this study was to examine atmospheric emission level in Kuje Area Council in the FCT of Nigeria. The specific objectives of the study were as follows: (i) to determine the pollution levels of $\mathrm{CO}_{2}$ in residential and commercial districts of Kuje; (ii) to determine its environmental effects in Kuje, FCT; and (iii) to determine its health implications on residents.

We assumed that $\mathrm{CO}_{2}$ outdoor emission levels are normal in residential districts and high in commercial districts of Kuje Area council. This research covers residential and commercial areas in Kuje Area Council within the FCT of Nigeria, to provide a basis for extensive and comparative analysis.

\section{Description of the study area}

Kuje Area Council is located between latitude $8^{\circ} 40^{\prime}$ and $9^{\circ} 00^{\prime}$ north of the equator and longitude $7^{\circ} 00^{\prime}$ and $7^{\circ} 40^{\prime}$ east of the Greenwich meridian. It is bordered on the north by Abuja Municipal Area Council, to the east by Nasarawa state, and to the west by Kwali Area council. It has a population of 97367 according to the 2006 Nigerian census report (Federal Government of Nigeria Official Gazette, 2007). Kuje Area Council is among the most developed of the six area councils; it falls within the semi-urban settlement location of the FCT. The bulk of the built-up areas are Kuchiyako, Lowcost estate, Pasali, etc., Figure 1 gives the boundary locations of the study area.

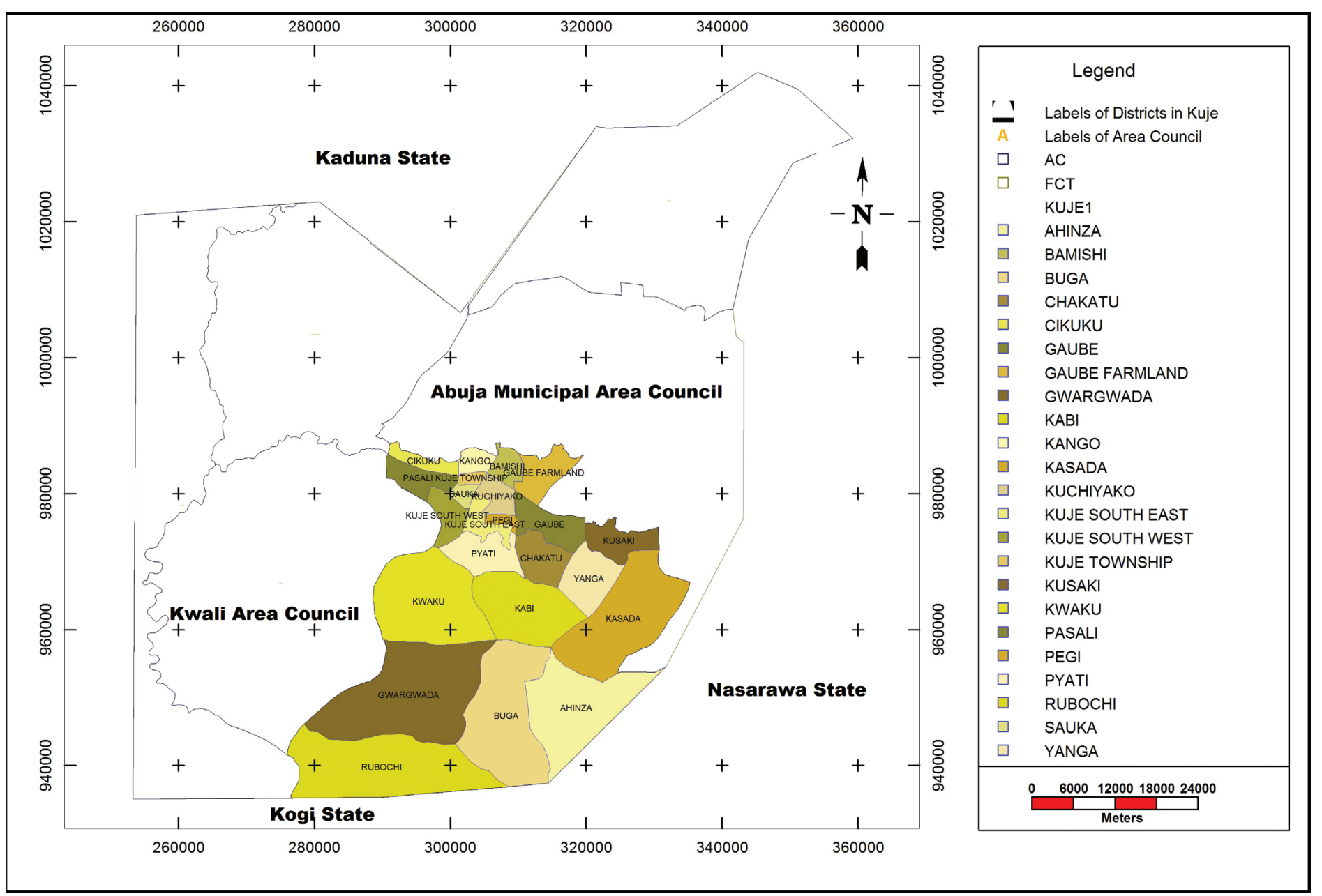

Figure 1. Map showing Kuje Area Council of the FCT Nigeria. Source: Adapted from Abuja Geographic Information System (AGIS) Abuja FCT, Nigeria 2016. 


\section{Climate}

The climate of the FCT is hot, humid, and tropical. It is such that its major elements have regimes that are transitional from those of the southern and the northern parts of the country.

From the information extrapolated from adjacent weather stations, the study area has a total annual rainfall of approximately $1650 \mathrm{~mm}$. About $60 \%$ of the annual rains fall during the months of July, August, and September (NIMET, 2010). A crucial climatic characteristic of this area is the frequent occurrence of squall lines heralded by thunder storms, lightening, strong winds, and high-intensity rainfall.

The temperature is highest and greatest during the dry season months from December to March, when the maximum temperature ranges between $30^{\circ} \mathrm{C}$ and $35^{\circ} \mathrm{C}$. During the wet season months from May to September the maximum temperature ranges between $25^{\circ} \mathrm{C}$ and $30^{\circ} \mathrm{C}$ (NIMET, 2010).

\section{Methods and materials}

The land-use patterns and population density were studied using purposive sampling techniques to guide in data acquisition. The primary $\mathrm{CO}_{2}$ field data were acquired directly from 50 specific residential and commercial locations in the study area at 2-hour intervals (from $0600 \mathrm{~h}$ to $2200 \mathrm{~h} \mathrm{GMT}$ ) with over 1200 observations. We used an AMPROBE $\mathrm{CO}_{2}-100$, $\mathrm{CO}_{2}$ gas detection instrument with a self-calibration capability of $\pm 30 \mathrm{ppm} \pm 5 \%$ reading $(0-5000)$ accuracy (which meets
European, American, Australian, and Nigerian standards), combined with a Garmin CX60 global positioning system to obtain the point location Universal Transvers Mercator coordinates.

The field observations were done in compliance with local and global regulations. Spatial point $\mathrm{CO}_{2}$ data value readings were collected (morning, afternoon, and evening), separately in 2-, 4-, 6-, and 8-hour time bands in the residential and commercial areas during the wet and dry seasons.

\section{Results}

\section{Dry season mean $\mathrm{CO}_{2}$ data for the residential district in Kuje Area Council}

The mean dry season $\mathrm{CO}_{2}$ results for the residential district in Kuje Area Council are presented in Figure 2. The details of each point in the residential district are shown in Table 1.

The mean dry season $\mathrm{CO}_{2}$ data from the residential district showed a minimum value of $574 \mathrm{ppm}$ at point 17 (P17 (by a housing development)), whereas the highest $\mathrm{CO}_{2}$ mean value was $694 \mathrm{ppm}$ at P3 (by an event centre). The lowest value was observed at $0600 \mathrm{~h}$ at the 2-hour time band, and the highest value was obtained at $2200 \mathrm{~h}$ at the 8 -hour time band. The graph in Figure 2 shows a distinct trend of $\mathrm{CO}_{2}$ emissions with higher values during the 4-hour time band and the 8-hour time band as tabulated in Table 1. However, the overall trend from morning to evening shows little fluctuation in the $\mathrm{CO}_{2}$ emissions (diurnal range).

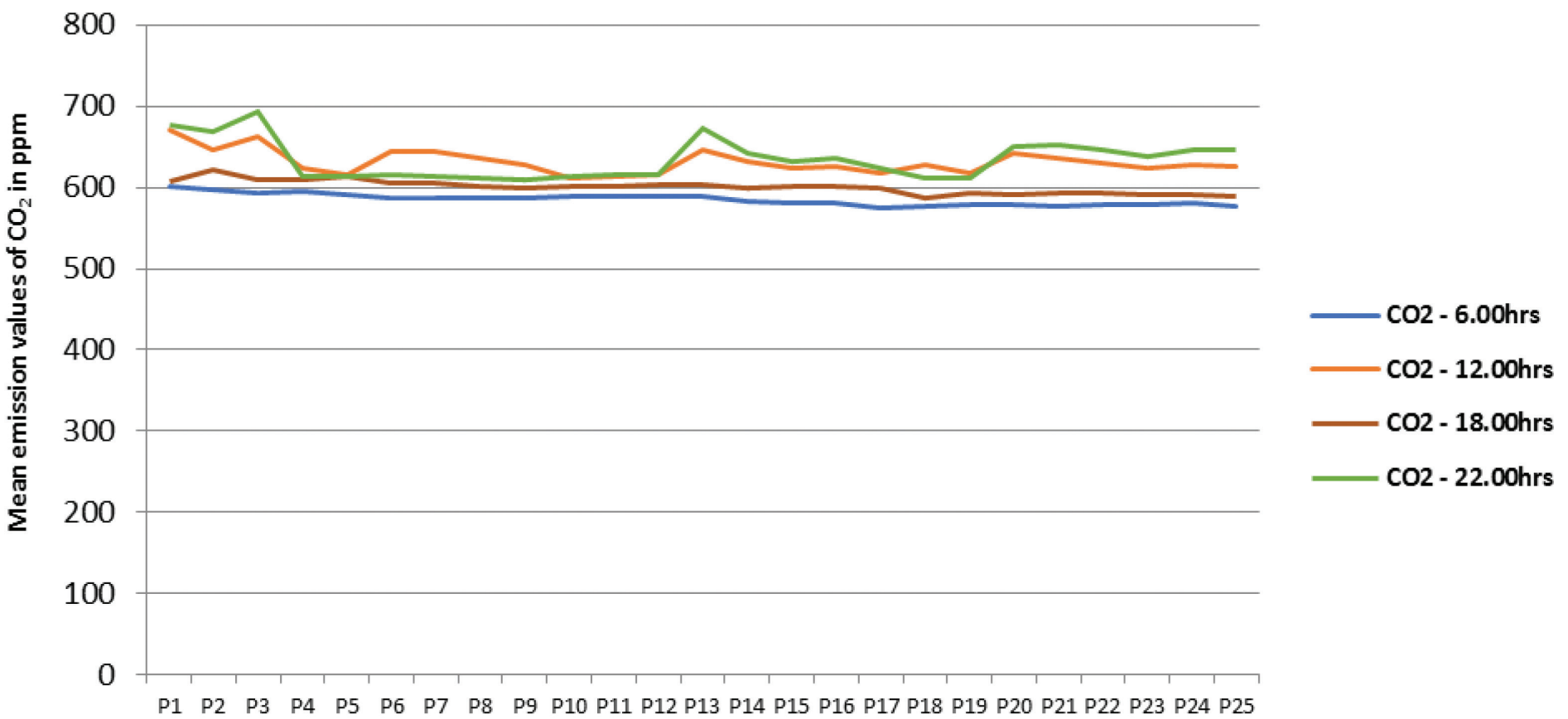

Sample Locations in Residential Districts

Figure 2. Graph showing mean $\mathrm{CO}_{2}$ dry season residential data for Kuje, F.C.T. Nigeria. 
Table 1. Mean dry season residential field $\mathrm{CO} 2$ data in Kuje Area Council in the Federal Capital Territory.

\begin{tabular}{|c|c|c|c|c|c|c|c|}
\hline \multirow[t]{2}{*}{$\mathbf{S} / \mathbf{N}$} & \multirow[t]{2}{*}{ Residential areas } & \multicolumn{2}{|c|}{ Location } & \multicolumn{4}{|c|}{ Mean $\mathrm{CO}_{2}$ emission (ppm) } \\
\hline & & $\begin{array}{c}\text { Coordinates } \\
\mathbf{N}\end{array}$ & $\begin{array}{c}\text { Coordinates } \\
\text { E }\end{array}$ & $0600 \mathrm{~h}$ & $1200 \mathrm{~h}$ & $1800 \mathrm{~h}$ & $2200 \mathrm{~h}$ \\
\hline & Kuje Low-cost Housing Estate & & & & & & \\
\hline P1 & Dr. Ekpendo Road junction & 0981794 & 0306423 & 601 & 671 & 607 & 676 \\
\hline P2 & Dr. Ekpendo Road I & 0981848 & 0306430 & 598 & 646 & 621 & 669 \\
\hline P3 & Dr. Ekpendo Road by FCTA Event Centre & 0981997 & 0306458 & 594 & 663 & 609 & 694 \\
\hline $\mathrm{P} 4$ & Kuje Lowcost housing estate junction & 0981812 & 0306325 & 596 & 623 & 609 & 614 \\
\hline P5 & Kuje Lowcost housing estate road & 0981871 & 0306390 & 591 & 615 & 613 & 614 \\
\hline P6 & Kuje Lowcost by RONNAWINS Fashion & 0981893 & 0306238 & 587 & 645 & 606 & 616 \\
\hline P7 & Kuje Lowcost by CHISCO rentals & 0981955 & 0306253 & 587 & 645 & 605 & 614 \\
\hline P8 & Kuje Lowcost Road by mosque & 0982057 & 0306182 & 587 & 636 & 601 & 611 \\
\hline P9 & Kuje Lowcost Road by mosque junction & 0982049 & 0306103 & 586 & 628 & 600 & 609 \\
\hline $\mathrm{P} 10$ & Setlement Road II off Wuru Street & 0982016 & 0305853 & 589 & 611 & 602 & 614 \\
\hline P11 & Setlement Road III off Wuru Street & 0981974 & 0305866 & 590 & 614 & 601 & 615 \\
\hline $\mathrm{P} 12$ & Wuru Street by Fine Touch Salon & 0981975 & 0305731 & 588 & 615 & 604 & 615 \\
\hline & Kuchiyako District & & & & & & \\
\hline P13 & Union Homes Crescent I & 0980426 & 0306038 & 590 & 646 & 603 & 672 \\
\hline $\mathrm{P} 14$ & Road 4 by Electricity transformer & 0980445 & 0305974 & 582 & 631 & 600 & 642 \\
\hline P15 & House B29 Road 4 Union Homes Est. & 0980408 & 0305954 & 581 & 623 & 601 & 632 \\
\hline $\mathrm{P} 16$ & House B29B Road 4 Union Homes Est. & 0980370 & 0305932 & 580 & 625 & 601 & 637 \\
\hline $\mathrm{P} 17$ & Road 4 by Abu Sidqu & 0980311 & 0305901 & 574 & 617 & 599 & 624 \\
\hline P18 & House B37 Road 4 Union Homes Est. & 0980162 & 0305837 & 577 & 627 & 587 & 612 \\
\hline P19 & House B38 Road 4 Union Homes Est. & 0980117 & 0305822 & 578 & 617 & 593 & 611 \\
\hline $\mathrm{P} 20$ & House D15A Road 3 Union Homes Est. & 0980091 & 0305869 & 578 & 642 & 592 & 650 \\
\hline $\mathrm{P} 21$ & House D13A Road 3 Union Homes Est. & 0980124 & 0305882 & 577 & 637 & 593 & 652 \\
\hline $\mathrm{P} 22$ & House D11 Road 3 by Water Reservoir & 0980166 & 0305900 & 579 & 630 & 593 & 646 \\
\hline $\mathrm{P} 23$ & House D9D Road 3 Union Homes Est. & 0980204 & 0305915 & 579 & 623 & 591 & 638 \\
\hline $\mathrm{P} 24$ & House D7D Road 3 Union Homes Est. & 0980257 & 0305937 & 580 & 627 & 591 & 647 \\
\hline $\mathrm{P} 25$ & House D5D Road 3 Union Homes Est. & 0980293 & 0305955 & 576 & 626 & 590 & 647 \\
\hline
\end{tabular}

\section{Dry season mean $\mathrm{CO}_{2}$ data for the commercial district in Kuje Area Council}

The mean dry season $\mathrm{CO}_{2}$ results for the commercial district in Kuje Area Council are presented in Figure 3. The details of each point in the commercial district are shown in Table 2.

The mean field data of $\mathrm{CO}_{2}$ in the commercial district showed a different trend in emissions, with a minimum value of $612 \mathrm{ppm}$ at P6 (by a shopping district) at $0600 \mathrm{~h}$ for the 2-hour time band, but a higher $\mathrm{CO}_{2}$ emission of 708 ppm was obtained at P23 (by a plaza). However, the highest values of $708 \mathrm{ppm}, 711 \mathrm{ppm}$, and $714 \mathrm{ppm}$ were recorded at $1800 \mathrm{~h}$ for the 6-hour time band at P4 (by a fuel station), P5 (inside the fuel station), and P22 (by a fast food establishment), respectively. At $1400 \mathrm{~h}$ for the 4-hour time band the highest $\mathrm{CO}_{2}$ value was at $\mathrm{P} 3$ by the fuel station, and the lowest $\mathrm{CO}_{2}$ value was at $\mathrm{P} 8$ by the supermarket. The lowest $\mathrm{CO}_{2}$ value at the 4-hour time band was above $600 \mathrm{ppm}$. Therefore, this implies that human activities contribute greatly to gas emissions (Table 2).

\section{Wet season mean $\mathrm{CO}_{2}$ data for the residential district in Kuje Area Council}

The mean $\mathrm{CO}_{2}$ results for the wet season in the residential district in Kuje Area Council are presented in Figure 4. The details of each point in the residential district are shown in Table 3.

The lowest mean $\mathrm{CO}_{2}$ data from field values was $541 \mathrm{ppm}$ at $\mathrm{P} 18$ at the 8 -hour time band. At $1800 \mathrm{~h}$, the 6 -hour time band was lowest at $579 \mathrm{ppm}$ at P23-P25 and was highest at $597 \mathrm{ppm}$ at P2 (Table 3). At $1400 \mathrm{~h}$, the lowest value of the 4-hour mean data was $598 \mathrm{ppm}$ at P23 (Table 3) and the highest value was $611 \mathrm{ppm}$ at P2. At $0600 \mathrm{~h}$, the 2-hour mean $\mathrm{CO}_{2}$ data had the highest value of $673 \mathrm{ppm}$ at P18 and the lowest value of 589 ppm at P18 (Table 3). 


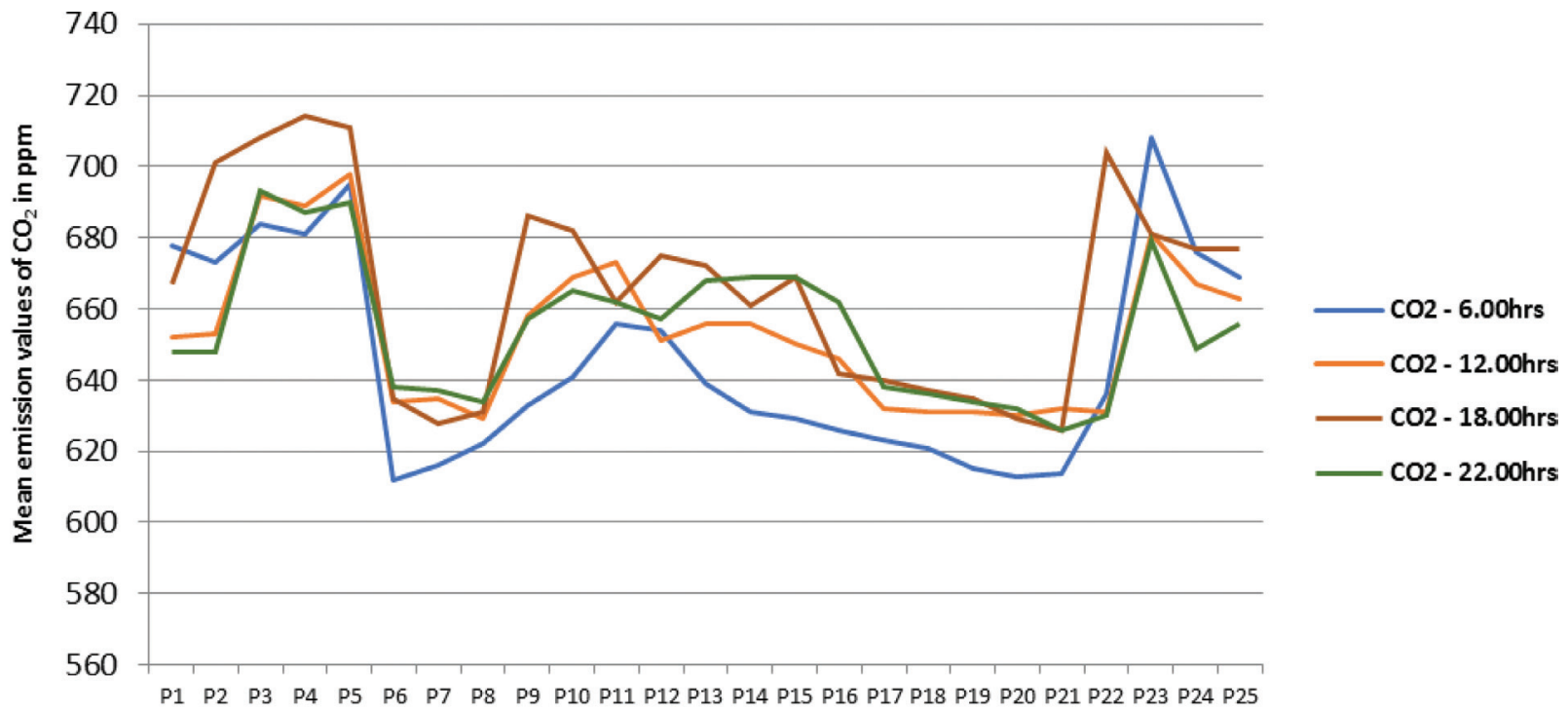

Sample Locations in Commercial Districts

Figure 3. Graph showing mean $\mathrm{CO}_{2}$ dry season commercial data for Kuje, F.C.T. Nigeria.

Table 2. Mean dry season commercial field C02data in Kuje Area Council in the Federal Capital Territory.

\begin{tabular}{|c|c|c|c|c|c|c|c|}
\hline \multirow[t]{2}{*}{$\mathbf{S} / \mathbf{N}$} & \multirow[t]{2}{*}{ Commercial areas } & \multicolumn{2}{|c|}{ Location } & \multicolumn{4}{|c|}{$\begin{array}{l}\text { Mean carbon dioxide } \\
\text { emission (ppm) }\end{array}$} \\
\hline & & $\begin{array}{c}\text { Coordinates } \\
\mathbf{N}\end{array}$ & $\begin{array}{c}\text { Coordinates } \\
\mathbf{E}\end{array}$ & $\begin{array}{c}0600 \\
h\end{array}$ & $\begin{array}{c}1200 \\
\text { h }\end{array}$ & $\begin{array}{c}1800 \\
h\end{array}$ & $\begin{array}{c}2200 \\
h\end{array}$ \\
\hline & Kuje/Pasali Road & & & & & & \\
\hline $\mathrm{P} 1$ & Kuje/Pasali Road by Anyi Chuks Inv. & 0981897 & 0305989 & 678 & 652 & 667 & 648 \\
\hline $\mathrm{P} 2$ & Kuje/Pasali Road by MARYAM house & 0981885 & 0306013 & 673 & 653 & 701 & 648 \\
\hline P3 & $\begin{array}{l}\text { Kuje/Pasali Road by A.A RANO fuel } \\
\text { station }\end{array}$ & 0981888 & 0305989 & 684 & 692 & 708 & 693 \\
\hline $\mathrm{P} 4$ & Kuje/Pasali Road inside A.A RANO & 0981879 & 0306013 & 681 & 689 & 714 & 687 \\
\hline $\mathrm{P} 5$ & Gomo Street by Unique Fast Food & 0981867 & 0305989 & 695 & 698 & 711 & 690 \\
\hline P6 & Kwakwara Street by Shoppers Corner & 0981766 & 0305989 & 612 & 634 & 635 & 638 \\
\hline P7 & Kwakwara Street by Future Hope Kiddies & 0981805 & 0306013 & 616 & 635 & 628 & 637 \\
\hline $\mathrm{P} 8$ & Kwakwara Street by Godwin supermarket & 0981856 & 0305989 & 622 & 629 & 631 & 634 \\
\hline P9 & Kuje/Gwags Road by GFU fuel station & 0981933 & 0306013 & 633 & 658 & 686 & 657 \\
\hline $\mathrm{P} 10$ & Kuje/Gwags Road by Four Square junction & 0981995 & 0305989 & 641 & 669 & 682 & 665 \\
\hline & Wowo Street & & & & & & \\
\hline P11 & Wowo Street in front of City Plaza & 0982006 & 0305017 & 656 & 673 & 662 & 662 \\
\hline $\mathrm{P} 12$ & Wowo Street inside City Plaza & 0982004 & 0305041 & 654 & 651 & 675 & 657 \\
\hline $\mathrm{P} 13$ & Wowo Street I & 0982056 & 0304997 & 639 & 656 & 672 & 668 \\
\hline $\mathrm{P} 14$ & Wowo Street by grinding machine & 0982090 & 0304982 & 631 & 656 & 661 & 669 \\
\hline $\mathrm{P} 15$ & Wowo Street by Tailor shop & 0982119 & 0304978 & 629 & 650 & 669 & 669 \\
\hline $\mathrm{P} 16$ & Kuje Zonal Education Office & 0982397 & 0304983 & 626 & 646 & 642 & 662 \\
\hline $\mathrm{P} 17$ & Kuje Junior Secondary School I & 0982421 & 0304951 & 623 & 632 & 640 & 638 \\
\hline $\mathrm{P} 18$ & Kuje junior Secondary school II & 0982438 & 0304836 & 621 & 631 & 637 & 636 \\
\hline $\mathrm{P} 19$ & Kuje Junior Secondary School III & 0982435 & 0304898 & 615 & 631 & 635 & 634 \\
\hline $\mathrm{P} 20$ & NUT Street junction & 0982373 & 0305156 & 613 & 630 & 629 & 632 \\
\hline $\mathrm{P} 21$ & Secretariat Road by God's Time Plaza & 0982076 & 0305398 & 614 & 632 & 626 & 626 \\
\hline $\mathrm{P} 22$ & Secretariat Road by Kuje/Gwags junction & 0981927 & 0305370 & 636 & 631 & 704 & 630 \\
\hline $\mathrm{P} 23$ & Secretariat Road by Dana Plaza & 0981883 & 0305667 & 708 & 681 & 681 & 679 \\
\hline $\mathrm{P} 24$ & Secretariat Road by FCMB & 0981873 & 0305854 & 676 & 667 & 677 & 649 \\
\hline $\mathrm{P} 25$ & Secretariat Road by Police Station & 0981860 & 0305978 & 669 & 663 & 677 & 656 \\
\hline
\end{tabular}




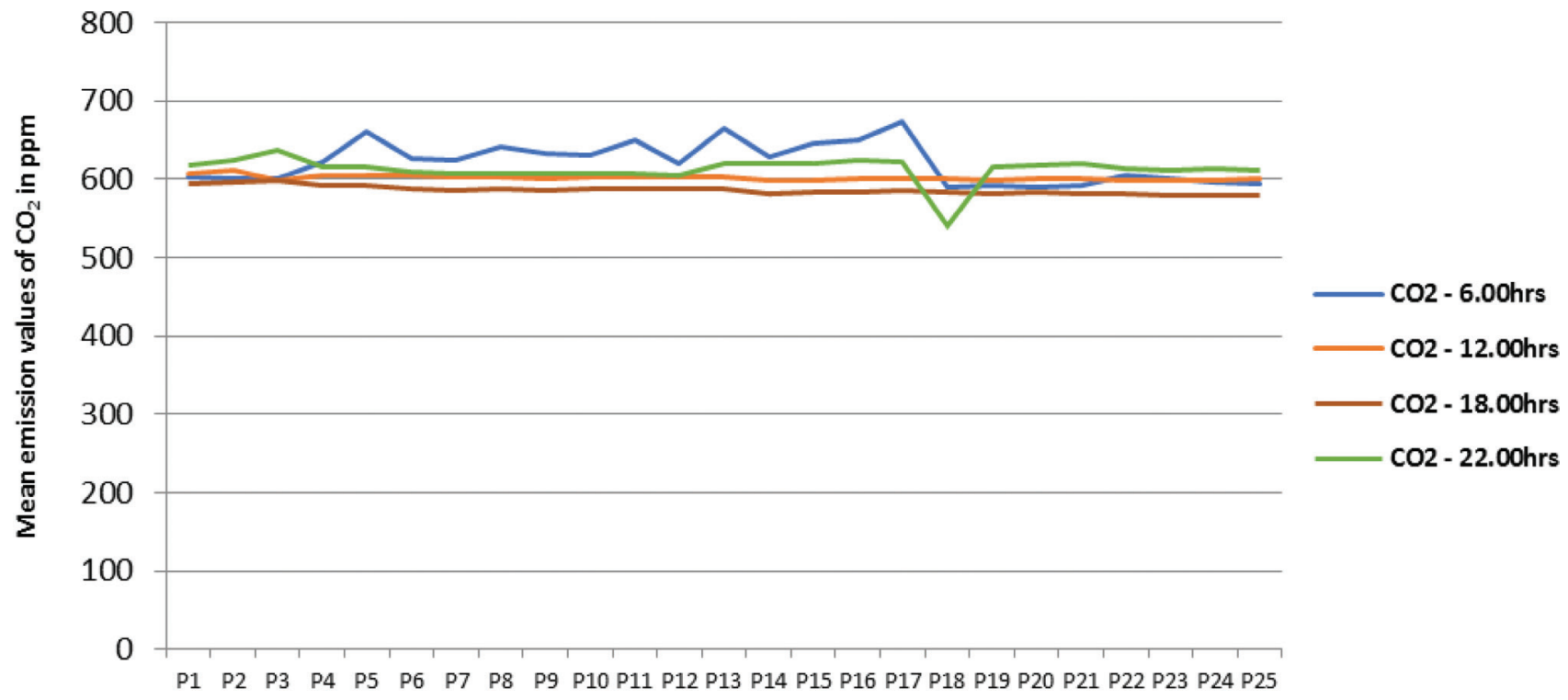

Sample Locations in Residential Districts

Figure 4. Graph showing mean $\mathrm{CO}_{2}$ wet season residential data for Kuje, F.C.T. Nigeria.

Table 3. Mean wet season residential field $\mathrm{CO}$ data in Kuje Area Council in the Federal Capital Territory.

\begin{tabular}{|c|c|c|c|c|c|c|c|}
\hline \multirow[t]{2}{*}{$\mathbf{S} / \mathbf{N}$} & \multirow[t]{2}{*}{ Residential districts } & \multicolumn{2}{|c|}{ Location } & \multicolumn{4}{|c|}{$\begin{array}{l}\text { Mean carbon dioxide } \\
\text { emission (ppm) }\end{array}$} \\
\hline & & $\underset{\mathbf{N}}{\text { Coordinates }}$ & $\begin{array}{c}\text { Coordinates } \\
\text { E }\end{array}$ & $0600 \mathrm{~h}$ & $1200 \mathrm{~h}$ & $1800 \mathrm{~h}$ & $2200 \mathrm{~h}$ \\
\hline & Kuje Low-Cost Housing Estate & & & & & & \\
\hline $\mathrm{P} 1$ & Dr. Ekpendo Road junction & 0981794 & 0306423 & 603 & 608 & 595 & 618 \\
\hline $\mathrm{P} 2$ & Dr. Ekpendo Road I & 0981848 & 0306430 & 600 & 611 & 597 & 625 \\
\hline P3 & Dr. Ekpendo Road by FCTA Event Centre & 0981997 & 0306458 & 601 & 599 & 598 & 637 \\
\hline P4 & Kuje Low-cost Housing Estate junction & 0981812 & 0306325 & 622 & 605 & 593 & 615 \\
\hline P5 & Kuje Low-cost Housing Estate Road & 0981871 & 0306390 & 660 & 605 & 593 & 615 \\
\hline P6 & Kuje Low-cost by RONNAWINS Fashion & 0981893 & 0306238 & 626 & 604 & 588 & 609 \\
\hline P7 & Kuje Low-cost by CHISCO rentals & 0981955 & 0306253 & 624 & 602 & 586 & 607 \\
\hline P8 & Kuje Low-cost Road by mosque & 0982057 & 0306182 & 642 & 602 & 587 & 608 \\
\hline P9 & Kuje Lowcost Road by mosque junction & 0982049 & 0306103 & 632 & 601 & 585 & 607 \\
\hline $\mathrm{P} 10$ & Setlement Road II off Wuru street & 0982016 & 0305853 & 631 & 602 & 587 & 607 \\
\hline $\mathrm{P} 11$ & Setlement Road III off Wuru street & 0981974 & 0305866 & 650 & 602 & 588 & 607 \\
\hline \multirow[t]{2}{*}{$\mathrm{P} 12$} & Wuru Street by Fine Touch Salon & 0981975 & 0305731 & 620 & 602 & 587 & 606 \\
\hline & Kuchiyako District & & & & & & \\
\hline $\mathrm{P} 13$ & Union Homes Crescent I & 0980426 & 0306038 & 664 & 603 & 587 & 620 \\
\hline P14 & Road 4 by Electricity transformer & 0980445 & 0305974 & 628 & 598 & 582 & 619 \\
\hline $\mathrm{P} 15$ & House B29 Road 4 Union Homes Est. & 0980408 & 0305954 & 645 & 599 & 583 & 620 \\
\hline $\mathrm{P} 16$ & House B29B Road 4 Union Homes Est. & 0980370 & 0305932 & 650 & 600 & 584 & 625 \\
\hline $\mathrm{P} 17$ & Road 4 by Abu Sidqu & 0980311 & 0305901 & 673 & 600 & 585 & 622 \\
\hline $\mathrm{P} 18$ & House B37 Road 4 Union Homes Est. & 0980162 & 0305837 & 589 & 600 & 583 & 541 \\
\hline $\mathrm{P} 19$ & House B38 Road 4 Union Homes Est. & 0980117 & 0305822 & 593 & 599 & 582 & 616 \\
\hline $\mathrm{P} 20$ & House D15A Road 3 Union Homes Est. & 0980091 & 0305869 & 590 & 600 & 583 & 617 \\
\hline $\mathrm{P} 21$ & House D13A Road 3 Union Homes Est. & 0980124 & 0305882 & 593 & 600 & 582 & 619 \\
\hline $\mathrm{P} 22$ & House D11 Road 3 by Water Reservoir & 0980166 & 0305900 & 605 & 599 & 581 & 613 \\
\hline $\mathrm{P} 23$ & House D9D Road 3 Union Homes Est. & 0980204 & 0305915 & 600 & 598 & 579 & 611 \\
\hline $\mathrm{P} 24$ & House D7D Road 3 Union Homes Est. & 0980257 & 0305937 & 597 & 599 & 579 & 613 \\
\hline P25 & House D5D Road 3 Union Homes Est. & 0980293 & 0305955 & 594 & 600 & 579 & 612 \\
\hline
\end{tabular}




\section{Wet season mean $\mathrm{CO}_{2}$ data for the commercial district in Kuje Area Council}

The mean $\mathrm{CO}_{2}$ wet season results for the commercial district in Kuje Area Council are presented in Figure 5. The details of each point in the commercial district are shown in Table 4.

The lowest mean $\mathrm{CO}_{2}$ data were at $0600 \mathrm{~h}$; the 2-hour time band value of $600 \mathrm{ppm}$ was at P10, whereas the highest value of $686 \mathrm{ppm}$ was at P23. At $1400 \mathrm{~h}$, at the 4-hour time band the highest mean $\mathrm{CO}_{2}$ value of $709 \mathrm{ppm}$ was at P23, and the lowest value of $620 \mathrm{ppm}$ was at P21. At $1800 \mathrm{~h}$ and $2200 \mathrm{~h}$, the 6-and 8-hour time bands had mean $\mathrm{CO}_{2}$ data of $713 \mathrm{ppm}$ and $705 \mathrm{ppm}$, respectively, and were highest at $\mathrm{P} 23$, whereas the lowest mean $\mathrm{CO}_{2}$ data for the 6-hour time band were $615 \mathrm{ppm}$ at P21 and for the 8-hour time band were 629 ppm at P20 and P21 (Table 4).

\section{Discussion}

The results showed that in the residential district during the dry season for the mean 2-hour time band, the lowest atmospheric $\mathrm{CO}_{2}$ emission value was $574 \mathrm{ppm}$ at $\mathrm{P} 17$ (Table 1). This value was observed during an off-peak period at $0600 \mathrm{~h}$ in the morning, whereas the highest $\mathrm{CO}_{2}$ mean value was $694 \mathrm{ppm}$ at P3, obtained during an 8-hour time band at $2200 \mathrm{~h}$ at night (Table 1). During the wet season in the residential district, the lowest $\mathrm{CO}_{2}$ mean data value of $541 \mathrm{ppm}$ was obtained at P18 during the 8 -hour time band at $2200 \mathrm{~h}$ at night (Table 3). The 2-hour mean $\mathrm{CO}_{2}$ data had the highest value of $673 \mathrm{ppm}$ at P18at $0600 \mathrm{~h}$ in the morning (Table 3).
In the commercial districts, the lowest mean atmospheric $\mathrm{CO}_{2}$ value for the dry season was $612 \mathrm{ppm}$ during the 2-hour off-peak time band at $0600 \mathrm{~h}$ in the morning at $\mathrm{P} 6$, whereas the highest value of $714 \mathrm{ppm}$ was obtained during the 6-hour peak time band at $1800 \mathrm{~h}$ at $\mathrm{P} 4$ (Table 2). The mean atmospheric $\mathrm{CO}_{2}$ data for the commercial district in the wet season were lowest at $600 \mathrm{ppm}$ during the 2 -hour time band of $0600 \mathrm{~h}$ at P10 and highest at $713 \mathrm{ppm}$ during the 6 -hour time band at $1800 \mathrm{~h}$ at P23 (Table 4).

The results showed that our asumption that outdoor emission levels are normal in residential districts and high in commercial districts of Kuje Area council is wrong. $\mathrm{CO}_{2}$ is high in the commercial and residential districts in Kuje, Nigeria, during both dry and wet seasons; however, the diurnal range is higher around the commercial areas compared with the residential areas. This further collaborated the fact that anthropogenic activities are contributing factors of increasing $\mathrm{CO}_{2}$ emission in Kuje, as indicated by the mean lowest and highest values in geospatial sample locations at Union Homes Estate during peak (1000 h to $1800 \mathrm{~h}$ ) and off-peak ( $0600 \mathrm{~h}$ in the morning and $2200 \mathrm{~h}$ ) periods. The high $\mathrm{CO}_{2}$ mean emission values were prevailent in the commercial districts and in the mean data obtained and analyzed. The dry and wet season mean $\mathrm{CO}_{2}$ data have shown high $\mathrm{CO}_{2}$ emissions of $>541 \mathrm{ppm}$ and $<713 \mathrm{ppm}$ collaborating the ESRL and NOAA research publication of mean monthly average measurement increase of $\mathrm{CO}_{2}$ from $398.93 \mathrm{ppm}$ to 402.25 ppm over 365 days. These mean geospatial location $\mathrm{CO}_{2}$ data emission values from Kuje-Nigeria were higher than ASHRAE and OSHA outdoor standards of 350-450 ppm, which were used as standards for this research.

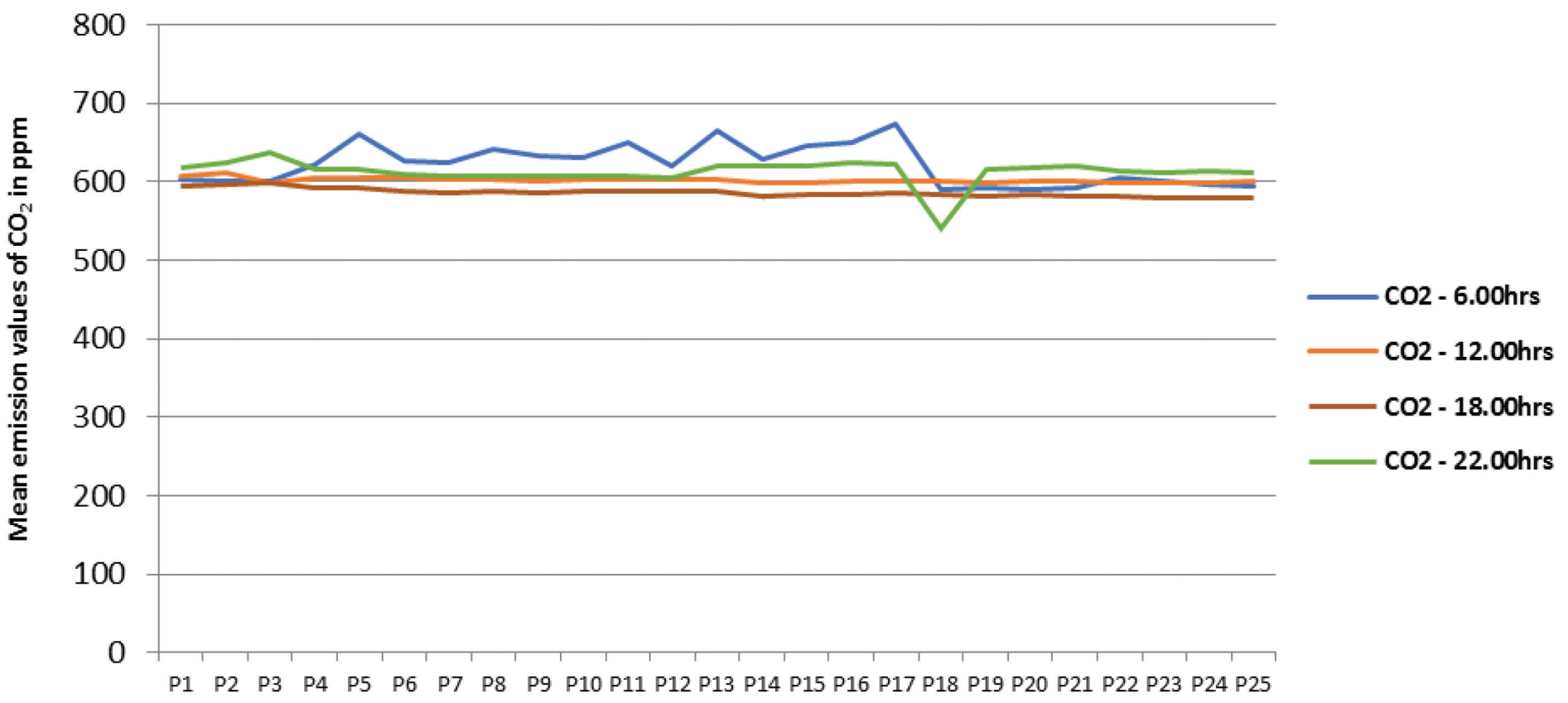

Sample Locations in Residential Districts

Figure 5. Graph showing mean $\mathrm{CO}_{2}$ wet season commercial data for Kuje, F.C.T. Nigeria. 
Table 4. Mean wet season commercial field $\mathrm{CO} 2$ data in Kuje Area Council in the Federal Capital Territory.

\begin{tabular}{|c|c|c|c|c|c|c|c|}
\hline \multirow[t]{2}{*}{$\mathbf{S} / \mathbf{N}$} & \multirow[t]{2}{*}{ Commercial districts } & \multicolumn{2}{|c|}{ Location } & \multicolumn{4}{|c|}{$\begin{array}{c}\text { Mean carbon dioxide emission } \\
(\text { (ppm) }\end{array}$} \\
\hline & & $\begin{array}{c}\text { Coordinates } \\
\mathbf{N}\end{array}$ & $\begin{array}{c}\text { Coordinates } \\
\text { E }\end{array}$ & $0600 \mathrm{~h}$ & $1200 \mathrm{~h}$ & $1800 \mathrm{~h}$ & $2200 \mathrm{~h}$ \\
\hline & Kuje/Pasali Road & & & & & & \\
\hline P1 & Kuje/Pasali Road by Anyi Chuks Inv. & 0981897 & 0305989 & 650 & 638 & 631 & 645 \\
\hline $\mathrm{P} 2$ & Kuje/Pasali Road by MARYAM house & 0981885 & 0306013 & 657 & 641 & 634 & 650 \\
\hline P3 & Kuje/Pasali Road by A.A RANO fuel station & 0981888 & 0305989 & 661 & 641 & 638 & 649 \\
\hline P4 & Kuje/Pasali Road inside A.A RANO & 0981879 & 0306013 & 667 & 642 & 638 & 648 \\
\hline $\mathrm{P} 5$ & Gomo Street by Unique Fast Food & 0981867 & 0305989 & 668 & 673 & 677 & 648 \\
\hline P6 & Kwakwara Street by Shoppers Corner & 0981766 & 0305989 & 616 & 648 & 632 & 649 \\
\hline P7 & Kwakwara Street by Future Hope Kiddies & 0981805 & 0306013 & 625 & 636 & 629 & 633 \\
\hline $\mathrm{P} 8$ & Kwakwara Street by Godwin supermarket & 0981856 & 0305989 & 615 & 633 & 625 & 630 \\
\hline P9 & Kuje/Gwags Road by GFU fuel station & 0981933 & 0306013 & 621 & 640 & 636 & 633 \\
\hline \multirow[t]{2}{*}{$\mathrm{P} 10$} & Kuje/Gwags Road by Four Square junction & 0981995 & 0305989 & 600 & 659 & 660 & 647 \\
\hline & Wowo Street & & & & & & \\
\hline P11 & Wowo Street in front of City Plaza & 0982006 & 0305017 & 639 & 659 & 660 & 646 \\
\hline $\mathrm{P} 12$ & Wowo Street inside City Plaza & 0982004 & 0305041 & 656 & 651 & 647 & 644 \\
\hline $\mathrm{P} 13$ & Wowo Street I & 0982056 & 0304997 & 645 & 648 & 642 & 642 \\
\hline $\mathrm{P} 14$ & Wowo Street by grinding machine & 0982090 & 0304982 & 646 & 638 & 631 & 637 \\
\hline $\mathrm{P} 15$ & Wowo Street by Tailor shop & 0982119 & 0304978 & 639 & 632 & 625 & 634 \\
\hline $\mathrm{P} 16$ & Kuje Zonal Education Office & 0982397 & 0304983 & 650 & 633 & 625 & 638 \\
\hline $\mathrm{P} 17$ & Kuje Junior Secondary School I & 0982421 & 0304951 & 647 & 631 & 624 & 636 \\
\hline P18 & Kuje Junior Secondary school II & 0982438 & 0304836 & 630 & 629 & 623 & 635 \\
\hline P19 & Kuje Junior Secondary School III & 0982435 & 0304898 & 629 & 627 & 621 & 633 \\
\hline $\mathrm{P} 20$ & NUT Street junction & 0982373 & 0305156 & 619 & 624 & 620 & 629 \\
\hline $\mathrm{P} 21$ & Secretariat Road by God's Time Plaza & 0982076 & 0305398 & 612 & 620 & 615 & 629 \\
\hline $\mathrm{P} 22$ & Secretariat Road by Kuje/Gwags junction & 0981927 & 0305370 & 620 & 623 & 616 & 630 \\
\hline $\mathrm{P} 23$ & Secretariat Road by Dana Plaza & 0981883 & 0305667 & 686 & 709 & 713 & 705 \\
\hline $\mathrm{P} 24$ & Secretariat Road by FCMB & 0981873 & 0305854 & 655 & 666 & 666 & 664 \\
\hline $\mathrm{P} 25$ & Secretariat Road by Police Station & 0981860 & 0305978 & 645 & 662 & 653 & 653 \\
\hline
\end{tabular}

These high $\mathrm{CO}_{2}$ data emission values have affected the environment as an increasing atmospheric temperature is prevalent in Kuje, and it warms the environment and causes fewer plants to provide less evaporative cooling; this may require a comprehensive research study. There are also issues of stress on residents, therefore reducing ability to work maximally. Tolerance limits of some plants are receded, resulting in low productivity.

There are several scientific and epidemiological studies on effects of high and increasing $\mathrm{CO}_{2}$ emissions in the global environment. Humans and mammals do not adapt to prolonged intake of toxic materials (Robertson, 2006). The increasing $\mathrm{CO}_{2}$ emission will adversely affect human health, causing cardiorespiratory issues and psychological reactions such as impaired vision, slowed reactions and responses, disorientation, or reduced attentional capacities that may jeopardize a worker's health and safety. (Kalaugher, 2008; Thind, 2013; Vercruyssen et al., 2007). The climate change effects due to sequestration of $\mathrm{CO}_{2}$ from the deforestation data of Kuje forest during an 8-year period grew by $40.67 \%$ (Badaru et al., 2016).

The high emission of $\mathrm{CO}_{2}$ values of $>541 \mathrm{ppm}$ and $<714 \mathrm{ppm}$ obtained in Kuje-Nigeria will pose serious health risks to the residents in the near future if the anthropogenic activities leading to the high $\mathrm{CO}_{2}$ emissions are not controlled or reduced. This should be done through advocacy, policy, and legislative framework. "If the atmospheric concentration of carbon dioxide reaches $600 \mathrm{ppm}$, the planet will have a permanent outdoor atmosphere exactly like that of a stuffy room" (Sarmiento et al., 2010). 


\section{Conclusion}

The results showed that the mean outdoor $\mathrm{CO}_{2}$ emission levels in Kuje were higher than the normal outdoor ASHRAE and OSHA standards of 350-450 ppm. The implication of the higher outdoor values of mean $\mathrm{CO}_{2}$ obtained is worrisome because as temperatures rise, increased toxicity levels and environmental effects are inevitable.

The quick implementation of strategic interventions such as planning, monitoring, and controlled mitigation of tree planting; transport regulations; education/awareness campaigns, etc., to reducing $\mathrm{CO}_{2}$ emissions is of utmost importance. The continuous rise in $\mathrm{CO}_{2}$ will adversely affect air quality and indoor pollution levels, which could lead to respiratory issues, fatigue, stress, and more.

\section{References}

Abdullahi, M. E., Okobia, E. L., \& Hassan, S. M. 2012. Assessment of ambient atmospheric concentration of volatile organic compounds in Abuja - Nigeria. J. Chem. Biol. Phy. Sci. 2(3): 1637-1647

Badaru, Y. U., Nassir, Y. M., and Musa Y. 2016. Change detection of Forestry Trees Sequestration of Carbon Dioxide is Falling: Case Study of Pasali-Kuje of the Federal Capital Territory, Nigeria. IJSRT 2(3): 252-257.

Farrar, C., Neil, J., and Howle, J. 1999. United States Geological Survey, Water-Resources Investigations Report on Magmatic Carbon Dioxide Emissions at Mammoth Mountain, California. https://pubs.usgs.gov/wri/wri98-4217/WRIR_98-4217.pdf [accessed 10 September 2016].

Federal Government of Nigeria Official Gazette. 2007. 94(24): 198

Federal Government of Nigeria. 2007. Legal notice on publication of the details of the breakdown of the national and state provisional total 2003 census. Official Gazette 24(94): 178-198.

International Volcano Health Hazard News (IVHHN). 2005. Gas and aerosol guidelines: Carbon dioxide. . In Discussion of known $\mathrm{CO}_{2}$ poisoning events associated with vulcanology. Available at: http://seis/bris.ac.uk/ glcjh/ivhnn/guidelines/gas/co2.html [27 September 2016].

Kalaugher, L. 2008. Carbon dioxide increase causes air pollution deaths. Available at: http://environmentalresearchweb.org/cws/ article/news/32401 [accessed 27 September 2016].

Lang-Yona, N., Levin, Y., Dannemiller, K. C., Yarden, O., Peccia, P., \& Rudich, Y. 2013. Changes in atmospheric $\mathrm{CO}_{2}$ influence the allergenicity of Aspergillus fumigatus. Glob. Change Biol. 19(8): 23812388. doi: $10.1111 / \mathrm{gcb} .12219$

Miller, J., Semple, S., and Turner, S. 2010. High carbon dioxide concentration in classroom: the need for research on the effects of children's exposure to poor indoor air quality at school. Occup Environ Med, 67(11): 799.

National Institute for Occupational Safety and Health (NIOSH). 197. Criteria for a Recommended Standard, Occupational Exposure to Carbon Dioxide. United States Department of Health, Education and Welfare, Public Health centre for Disease Control. https:// www.cdc.gov/niosh/pdfs/76-194a.pdf. [accessed 27 September 2016].

National Institute for Occupational Safety and Health (NIOSH). 1996. Documentation for Immediately Dangerous to Life or Health Concentrations (IDLHs) for carbon dioxide. Available at: www.cdc.gov [accessed 27 October 2016].

Nelson, L. 2000. Carbon dioxide poisoning. Summary of physiological effects and toxicology of $\mathrm{CO}_{2}$ on humans. J. Emerg. Med. 32(5): 36-38

Nigeria Meteorology Agency (NIMET). 2010. Weather report data sheet.

Okobia, L. E. 2012. Spatial and seasonal variations of ambient air quality in Abuja, Nigeria. An Unpublished M.Sc. Dissertation, University of Abuja.

Rice, A. S. 2004. Human Health Risk Assessment of $\mathrm{CO}_{2}$ : Survivors of Acute High-Level Exposure and Populations Sensitive to Prolonged Low-Level Exposure. 3rd Annual Conference on Carbon Sequestration, 3-6 May 2004, Alexandria, VA, USA.

Robertson, D. S. 2006. Health effects of increase in concentration of carbon dioxide in the atmosphere. Curr. Sci. 90(12): 1607-1609

Sarmiento, J. L., Gloor, M., Gruber, N., Beaulieu, C., Jacobson, A. R., MikaloffFletcher, S. E., 2010. Trends and regional distributions of land and ocean carbon sinks. Biogeosciences. 7: 2351-2367. doi: $10.5194 /$ bg-7-2351-2010

Thind, A. 2013. The effect of carbon emissions on human health. Available at: https://prezi.com/cy3vzyg2axgj/the-effectof-carbon-emissions-on-human-health/ [accessed 27 September 2016].

United States Earth System Research Laboratory (ESRL)/National Oceanic and Atmospheric Administration (NOAA). 2016. Globally average carbon dioxide concentration at the surface. Available at: http://www.esrl.noaa.gov/gmd/ccgg/trends/index.html [accessed 10 September 2016].

USEPA. 2016. United States Environmental Protection Agency overview on greenhouse gases emission. Available at: https://www.epa. gov/ghgemissions/overview-greenhouse-gases [accessed 27 September 2016].

Vercruyssen, M., Kamon, E., \& Hancock, P. A. 2007. Effects of carbon dioxide inhalation on psychomotor and mental performance during exercise and recovery. Int J. Occup. Saf. Ergon. 13(1): 15-27. doi: $10.1080 / 10803548.2007 .11076705$ 